\title{
The Public Participation in the Drafting of Legislation in Hungary
}

\author{
László Vértesy \\ National University of Public Service; Hungary \\ vertesy.laszlo@uni-nke.hu
}

\section{ABSTRACT}

The legitimacy of legislation is crucial for modern democracies. This paper provides a brief but detailed description and legal, quantitative analysis of this process, drawing attention to the most significant Hungarian techniques. According to the main provisions of Act CXXXI of 2010 on public participation in the drafting of legislation, public consultations are to be carried out within the framework of general or direct consultations. The general consultation is mandatory and open for the public, all draft bills, governmental decrees and ministerial decrees drafted by ministries are to be published on the Government's webpage. The direct consultation is based on strategic partnerships between the relevant ministries and stakeholders, outstanding organisations. In Hungary, it is the responsibility of the minister competent to draft the legislation to open and conduct public consultation and to process the received comments. These mandatory and optional processes strengthen the legitimacy and the acceptance of legislation. As a consequence of this the legal provisions meet with the social requirements, and they can be applied as a best practice for other countries.

Keywords: public participation, legislation, law making, drafting, public consultation

$J E L: K 23$

\section{Introduction}

The public participation in the drafting of legislation is one of the key elements in the legitimacy and the acceptance of legislation. In connection to the topic, the question is, whether and how can the state strengthen this, and how can it involve the populace more efficiently into the drafting of legislation procedure. The main hypothesis can be formulated as follows: are the legal obligation of public participation and mandatory public consultations capable to improve the legitimacy of legislation. Another question is whether the existing legislation provides an appropriate framework to involve the civil society organizations, NGOs, and the populace - by using their advisory power - into the process of legislation. The main objective of this paper is to present and analyse the public participation process, drawing attention 
to the most significant Hungarian techniques, and evaluate the results. One of the goals is, to show whether the rules work in the practice, and whether they are in accordance with the desirable political and social, legal aims. Another purpose is, to draw the attention of the decision and policy makers to this technique, which could be applied as a best practice for other countries. ${ }^{1}$

The research is mainly based on legal methodology with quantitative approach. The legal method is based on the classical interpretation types: grammatical, historical, logical, systematic, which are completed by the teleological and constitution conformity. Furthermore, the analysis takes into consideration not just the letter of the law, but the intentions of the lawmakers and opinions of the involved and relevant law appliers and practitioners. For comparison, the EU regulations are an important initiation. Besides the legal methodology, the study employs the quantitative approach. The paper contains some statistics to evaluate the results in figures. Based on the analysis of the relevant EU and Hungarian law sources and data, conclusions and critique can be drawn up.

\section{Public Participation}

All modern constitutions and fundamental or basic laws contain and declare the concept and principle of popular sovereignty, which essentially means that the people are the ultimate source of public power or government authority. The concept of popular sovereignty holds simply that in a society organized for political action, the will of the people as a whole is the only right standard of political action (Peters, 1978, p. 1). In our topic, it can be regarded as an important element in the system of the checks and balances, and representative democracy. Therefore, the people are implicitly entitled even to directly participate in the process of law making. This role of linking citizens and their government and legislators is closely related to the concept of legitimacy. According to the Regional Environmental Centre for Europe: 'Openness should be a rule in a democracy, and secrecy an exemption'. From this point of view, the principle of more-public-involvement-better-results could equally apply to the linkage and legitimation functions of legislatures in a democracy. The linkage between citizens and their government is obviously strengthened when the public has ample opportunity to have their concerns heard by the legislature (Kurtz, 1997, p. 2), and there is no consistent link between citizen knowledge and the support of legislatures (Baker, Bennett, Bennett, \& Flickinger, 1996). The exercise of democratic control over the legislative system and the policy-making process can occur even when the public has only an elementary understanding of the national legislative institution and its membership. Civic education is a vital strategy for strengthening public participation and confidence in the legislative process (Kurtz, 1997, p. 13).

1 The author was involved in the Regional Convention on European Integration of Serbia in 2015, where the topic was the cooperation between state and civil sector, and several national practices were shown to form a best and suitable practice for the candidate countries, even in the field of legislation. 
Public participation is an all-encompassing label used to describe the various mechanisms that individuals or groups may use to communicate their views on a public issue (Pring \& Noé, 2002, p. 15). Legislatures use various methods to provide information to the public about the legislative process and to bypass the media and communicate directly with the public. The following options as mediums can be utilised and operated for sharing information and facilitating public participation: newspapers, parliamentary publications (such as the debate), wide circulation of parliament order papers, radio, television, fax broadcasting, electronic mail (e-mail) and the internet or other IT devices. ${ }^{2}$ For each option, it is important to examine the advantages and disadvantages, requirements for the successful implementation and utilisation, financial and technical implications, accessibility by the general public, sustainability; cost and benefit analysis, and the level and quality of public participation facilitated by each medium. ${ }^{3}$ In brief, none of these options are in themselves a perfect fit for public participation initiative. On that basis, it is recommended that a combination of a few practical options should be considered to facilitate primarily information flow and thereafter provide public access to the drafting of legislation. In most cases, the electronic mail and the direct involvement of the stakeholders are the most expedient solutions. The ultimate form of public participation in the legislative process is direct democracy through referenda or initiatives. However, it also needs to be noted, that the ideal situation would be to engage every member of the public in discussions during the legislation, but according to experience this is unrealistic and practically impossible. Political parties and election campaigns perform a vital role in providing voters with opportunities to express their public policy preferences and in shaping the positions of their elected representatives.

The Charter of Fundamental Rights of the European Union brings together in a single document the fundamental rights protected in the EU and it is based on the principles of democracy and the rule of law. According to Article 41 (Right to good administration), every person may write to the institutions of the Union in one of the languages of the Treaties and must have an answer in the same language. Article 44 defines the right to petition, any citizen of the Union and any natural or legal person residing or having its registered office in a Member State has the right to petition the European Parliament. But the public participation in legislation is not included. The right of petition is open to any EU citizen and in order to be admissible, petitions must concern matters which fall within the EU's fields of activity and which affect the petitioners directly (Marzocci, 2016). The procedure for dealing with petitions is laid down in Rules 215 to 218 of, and Annex VI (XX) to, Parliament's Rules of Procedure, which confer responsibility on a parliamentary committee, currently the Committee on Petitions. It is important to mention, that the EU Directive $90 / 313$ of 7 June 1990 on the freedom of access to information

2 For example the Rio Grande do Sul State Legislative Assembly in Brazil provides a touch screen computer terminal that helps people learn about their legislators and the legislative process.

3 For details see Mijiga (2001). 
on the environment, ${ }^{4}$ is one of the first binding pieces of European legislation that deal with public participation. A recent and very important development concerning public participation is the recognition of it as a basic human right. And this was the central theme of the Arrhus Convention (1998). This Convention guarantees people the right of access to information, public participation and the right to justice.

The implementation of the Charter of Fundamental Rights of the European Union is obligatory for all the member states of the EU, but they are entitled to adopt and enact more rights. Article VI of the Fundamental Law of Hungary states that everyone shall have the right to the protection of his or her personal data, as well as to access and disseminate data of public interest. In accordance with the EU law, Article XXV of the Fundamental Law of Hungary declares that everyone shall have the right to submit, either individually or jointly with others, written applications, complaints or proposals to any organ exercising public power. This right of petition can be exercised by anybody, who is entitled by rights from the Fundamental Law and is entitled to participate in public affairs. ${ }^{5}$ The right to submit an application, complaint or proposal demands that the organs exercising public power do not prevent or hamper such submission. Accordingly, if the competent organ denies accepting a complaint, the right would be violated. The addressee can be any organ (state or municipal alike) exercising public power and not only those that bear the function under a separate legal regulation to examine and adjudge complaints (Csink, Schanda, \& Varga, 2012, pp. 192-193).

\section{Drafting of Legislation}

Under the concept of the Rule of Law or the Rechtsstaat, all the state interventions and actions need to be regulated and prescribed by the law. In the most relevant issues, acts have to be adopted, but other regulations of the executive branch (government, ministers, and local governments) e.g. decrees are equally relevant. One of the most important informal functions of the legislature is to provide legitimacy to government actions. According to the above-mentioned public legitimacy, public-involvement (can) strengthen the level of the checks and balances.

In Hungary, at the end of the 1980's even some provisions on public participation could be found, but they were not relevant in the practice and were originated from the political transformation. The former Act XI of 1987 on Legislation contained the possibility of the public consultation, and declared the compulsory involvement of the law enforcement agencies, civil organizations and representative bodies. But these were just formalities, there were no official practice or forums for the people or stakeholders to become acquainted with the drafts or express their opinions, recommendations

4 This directive is amended by Directive 2003/4/EC.

5 his means every natural person without prejudice to their nationality and residence. 
(Fridli \& Paskó, 2000). Currently the Act CXXX of 2010 on Legislation defines precisely the most important requirements of law making: scope of the act, amendments, prohibition of retroactive validity, sufficient date of entry into force, preparation of legislation, constant review of the legal system, promulgation and publication, official and non-official legal databases. In our case, the рарег will focus on the preparation section. Furthermore, the Act CXXXI of 2010 on public participation in the drafting of legislation contains the relevant details, the mandatory and optional forms, possibilities and the guarantees (e.g. disclosure, data protection).

During the preparation process, it is the duty of the minister responsible for drafting the legislation to develop the professional content of the legislation. The most important requirements are the following: meeting the form and content conditions under the Fundamental Law, fitting in the unity of the legal system, meeting the obligations under international law and European Union law, and meeting the professional requirements of the legislation.

The preparer of the legislation attaches an explanation (statement of reasons), which describes the social, economic and professional reasons and goals that make the proposed regulation required, and also describes the impacts of the legislation. If under the EU treaties or according to the legislation of the European Union, this is compulsory, the draft shall be sent to the certain institutions of the European Union and the Member States of the European Economic Area for prior notification and commenting. If the law provides expressly the right of a state or local government or other organizations to express an opinion and evaluation on the drafts, the preparer of the legislation must ensure that the body shall be allowed to exercise this right. The ргерагег of the legislation ensures that the drafts are available for the public and comments can be submitted. The details of public participation in drafting of legislation are defined by a separate act.

The Decree No. 12/2016. (IV. 29.) of the Minister of the Prime Minister's Office on Ex-ante and Ex-post Impact Assessment prescribes the requirements pertaining to the ex-ante and ex-post impact assessment of the bills to be put forward by the Government, as well as the draft government decrees and ministerial decrees. The impact assessment is an information collection and analysing procedure, the fundamental objective of which is to increase the efficiency of regulations. It includes the analysis of the expected consequences of the regulation aligned to the details of and carried out in a period relevant to the assumed impacts of the regulation, followed by the summary of findings to support sound decision-making. ${ }^{6}$ The impact assessment sheets contain the relevant social dimensions, public health, competitiveness, fiscal and budgetary, administrative cost, environmental, and employment and labour market impacts. Not all sheets investigate impacts with the same degree of detail and thoroughness. Further assessment sheets cover methodologies

6 Decree No. 12/2016. (IV. 29.) of the Minister of the Prime Minister's Office on Ex-ante and Ex-post Impact Assessment, Article 22. 
to address benefits and costs and how to account for risk, as well as post-implementation evaluations (OECD, 2015, p. 83). The summary of the ex-ante impact assessment needs to be made public on a website and available for public participation.

\section{Public Participation in the Drafting of Legislation}

The National Assembly adopted on 22nd November 2010 the Act CXXXI of 2010 on public participation in the drafting of legislation ${ }^{7}$, to foster within the framework of good governance the engagement of the widest possible range of social segments in developing legislation, laying the foundations of broad-based legislation to serve the public good, and thus improve the quality and enforceability of legislation, which together constitute the indispensable prerequisites of the Good State. ${ }^{8}$ The Act entered into force on 1st January 2011, and contains detailed rules for the public consultation process with the public applicable to legislative drafts.

The scope of this Act does not extend to the decrees of local governments. In the case of municipalities, the Act CLXXXIX of 2011 on Local Governments in Hungary also does not contain any provisions on the public participation. Therefore, it depends on the decisions of the councils (body of representatives) of the local government to lay down in a by-law the rules of public participation in developing its by-laws in accordance with local conditions. Usually public hearing is an often-applied good practice. Public hearings, by definition, аге open to the public, the only exceptions are generally for individual privacy matters (such as personnel decisions) (Kurtz, 1997, p. 7), and local government issues of business interest.

The publicity of the so-called Legislative Plan and Legislative Brief are two other guaranteeing elements stipulated in the Act CXXXI of 2010. These documents can be regarded as short-term legislative programmes, which contain the necessary main directions and key topics for law making. According to the relevant provisions the Legislative Plan of the Government - in view of international obligations; requirements in relation to alignment with European Union obligations; the decisions of the National Assembly and the Constitutional Court; and the objectives of the Government's agenda - is determined by resolution adopted by the National Assembly in the course of its ordinary sessions. This reinforces the public control via the National Assembly due the indirect democracy. ${ }^{9}$ Furthermore, it is the duty of the minister responsible for drafting the legislation, to publish his or her Legislative Brief in respect of the legislative planning period of the Government on a designated website. The legislative brief of the minister competent to draft the legislation includes the titles of the legislative drafts to be prepared

7 In other translation, it can be found as Act CXXXI of 2010 on Public Participation in Developing Legislation.

8 Act CXXXI of 2010 on Public participation in the drafting of legislation, Preamble

9 Act CXXXI of 2010 on Public participation in the drafting of legislation, Article 3 
by him or her, a short summary of their contents, and the scheduled dates of making public the legislative drafts. ${ }^{10}$ Published ministerial legislative briefs may not be removed from the website for one year from their publication.

The primal instrument of public participation in the drafting of legislation is public consultation. The terminology 'public consultation' is defined by the Act as any kind of comments by natural persons and non-governmental and non-municipal organisations of legislative drafts prepared by the ministers. The scope of subjects is really wide, the commentators can be any single natural person, and - maintaining their independence - non-governmental and non-municipal organisations: associations, foundations, chambers, public bodies, interest representative bodies, trade unions, human rights defenders, other stakeholders. Even business and commercial companies are entitled, but for them the public bodies, interest representative bodies, the Chamber of Commerce and Industry are the more suitable possibility.

The scope of the Act extends to the above-mentioned narrow sense of public consultation, but also extends to regulatory concepts serving as the basis of legislative drafts prepared by the ministers. ${ }^{11}$ The provisions do not affect the rights to comment and to consultation specified in other legislation or in other public law organisation governing instruments. The scope of the act does not extend to the drafting of legislation on states of emergency, hazard situations and pre-emptive protection measures. ${ }^{12}$ According to the Fundamental Law the Government is not authorised to draft legislation, it bears solely the power to adopt government decrees, and - pursuant to Article 6 - propose bills. Ministers - if they are not MPs - are not entitled to propose bills directly to the National Assembly. ${ }^{13}$

Because of legal policy considerations, the Act enumerates some exceptions: legislative drafts on payment obligations, state subsidies, the Budget and its execution, funding received from the European Union and international sources, the promulgation of international treaties, and the establishment of organisations and institutions. ${ }^{14}$ In the cases of these topics, the draft is not required to be submitted for public consultation. Another reasonable list: a draft or concept may not be submitted for public consultation in the event that such consultation compromises the protection of particularly important defence, national security, financial, foreign, nature

10 Act CXXXI of 2010 on Public participation in the drafting of legislation, Article 4

11 Act CXXXI of 2010 on Public participation in the drafting of legislation, Article 1

12 According to the Fundamental Law of Hungary, the special legal orders are the followings: state of national crisis (Article 49), state of emergency (Article 50), state of preventive defence (Article 51), terror threat-situation (Article 51/A), unexpected attacks (Article 52) and state of extreme danger (Article 53).

In addition, decrees of the National Defence Council adopted during a state of national crisis and decrees of the President of the Republic adopted during a state of emergency shall also be rules of law. In the other special legal orders the Government adopt decrees.

13 Fundamental Law of Hungary, Chapter Government and Article 6

14 Act CXXXI of 2010 on Public participation in the drafting of legislation, Article 5 
conservation, environmental, or heritage protection interests of Hungary. ${ }^{15}$ Finally, a legislative draft shall not have to be submitted for public consultation in the event that a prevailing public interest warrants its rapid passage.

First the common rules are defined, which are followed by the specific provisions, because the Act distinguishes two forms of public consultation: general consultation and direct consultation. The Act declares three fundamental principles in connection with public consultation. In the course of public consultation and drafting legislation

- the widest possible range (in particular those of socio-economically marginalised and disadvantaged groups) of comments are ensured, and these are made public;

- the transparency and maximum publicity of consultations need to be provided;

- the participants are obliged to act in cooperation. ${ }^{16}$

In accordance with the scope of the act the draft and the explanation of the acts, government decrees, and ministerial decrees (hereinafter jointly referred to as draft) need to be submitted for public consultation. Prior to submitting a draft for public consultation, the concept of the draft may also be submitted for public consultation subject to the competent minister's decision. ${ }^{17}$ It is the responsibility of the minister competent to draft the legislation to open and conduct public consultation and to process the comments received. For reasons of clarity in the event that the published legislative draft is aimed to amend more than one fifth of the provisions of other laws, the amended and consolidated text of the effective legislation together with the proposed amendments separately marked shall be published on the website. ${ }^{18}$ The minister responsible for drafting a given bill is also responsible for publishing the draft and for holding a public consultation.

15 Act CXXXI of 2010 on Public participation in the drafting of legislation, Article 5 and 6

16 Act CXXXI of 2010 on Public participation in the drafting of legislation, Article, 2

17 Act CXXXI of 2010 on Public participation in the drafting of legislation, Article, 5

18 Act CXXXI of 2010 on Public participation in the drafting of legislation, Article, 6 
Figure 1. The ratio of published laws by type of submitter per year

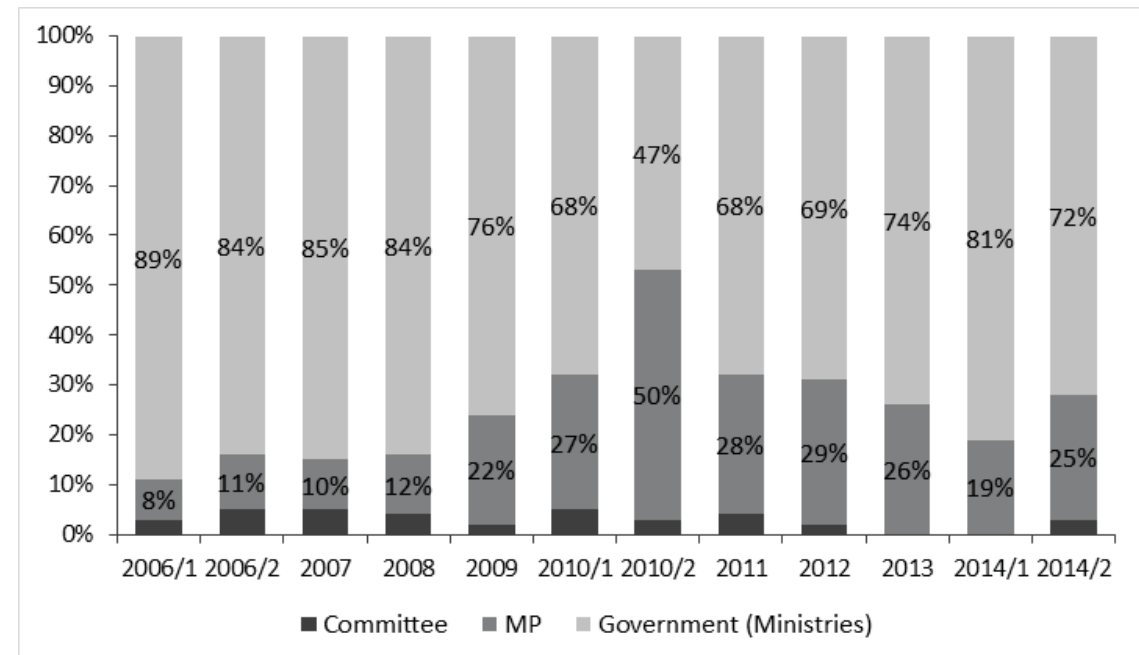

Note: When data concerning one year are represented in two parts, an election took place or the prime minister was changed.

Source: Corruption Research Centre (CRC, 2015)

The statistics of Corruption Research Centre show that usually more than 75-80 percent of the bills submitted by the Government were drafted exclusively in the ministries. So, in most of the cases the public consultation is necessary. Since 2010 a higher number of bills submitted by members of the National Assembly have been passed compared to the former governmental period, which also translates into a considerably higher proportion of these laws under the second Orbán government compared to the previous governments. The share of bills submitted by MPs of the ruling parties also reached a peak in 2010, until the first year of the second Orbán government. A probable cause of this is that in the first months after the change of government the bureaucracy was not altered (CRC, 2015, p. 43). In 2011 there was a sharp decline regarding this rate, however it remained high compared to the period before 2010 .

According to the methodological guidelines of the Office for National Economic Planning (Nemzetgazdasági Tervezési Hivatal - NTH) the following rules and regulations, among others, must be followed in a general public consultation (NTH, 2012):

- the consultation must be carried out at such point in the law-making process that it may influence the opinions of lawmakers;

- the planned legislative timeframe must leave room for the public to formulate useful opinions and suggestions. Experience shows that the more time is allowed, the better the feedback. (However, a legal minimum is not defined.); 
- the documentation released in conjunction with a public consultation should be easily understandable, concise and jargon-free;

- the framework must help the people quickly recognize and decide whether a specific consultation and the associated published documentation are relevant to their lives. To this end, the creation of a public information table summarizing the different consultations is necessary.

The forms of public consultation are the following: making comments via the link available on the website (hereinafter referred to as general consultation), and comments made by persons, institutions and organisations engaged by the minister competent to draft the legislation (hereinafter referred to as direct consultation). ${ }^{19}$ The main difference between the forms is that, while general consultations are mandatory, direct consultations are optional. But this is not a closed, exhaustive list, because the minister responsible for drafting the legislation - upon the authorisation of this Act - may in addition use other forms of consultation.

\subsection{General Consultation}

Holding a general consultation is mandatory in the course of public consultation in all cases. The draft or concept submitted for public consultation needs to be public and available on the website. In addition to the draft, the summary of the ex-ante impact assessment - as set forth in the Act on Legislation - needs to be uploaded. ${ }^{20}$ Even drafts not submitted for public consultation should also be made public on the website. On every homepage of the Hungarian ministries (via http://www.kormany.hu), a link can be found with the title of 'general consultation'. On this link, there is a long list of the relevant drafts, where the topic, the full text with the explanation in PDF form, the upload date, the commenting deadline and the official receiving e-mail address are located. The published drafts may not be removed from the website for one year from publication.

Everyone is entitled to make comments on the draft or concept submitted for public consultation via the electronic mail address provided on the website. Using the e-mail address published on the webpage, people may express an opinion on the draft or concept subject to public consultation. Return receipts are sent on the comments received. To ensure that the general consultation bears enough importance the comments received anonymously are ignored and deleted. The names and electronic addresses of commenters - for purposes of sending return receipts, publishing a summary and the list of commenters, and making subsequent comments - are handled by the minister competent to draft the legislation for no longer than

19 Act CXXXI of 2010 on Public participation in the drafting of legislation, Article, 7

20 Act CXXXI of 2010 on Public participation in the drafting of legislation, Article, 7 and 8 
one and a half years from the entry into force of the commented legislation. ${ }^{21}$ In the event that the commented legislation does not enter into force the name and electronic address of the commenter are deleted within no longer than one year of the receipt of the comment. The personal data of the commenters are handled in accordance with the Act CXII of 2011 on Informational Self-Determination and Freedom of Information (Privacy Act). To facilitate the access to the general consultation the consent to handling the personal data of the commenter is considered to be granted pursuant to the presumption in the Privacy Act. ${ }^{22}$ The commenter's attention needs to be drawn clearly to this fact and to the rules of data handling with regard to the commenter's data before the comment is made.

Table 1. The feedback and views of participants on electronic mail (e-mail)

\begin{tabular}{|l|l|}
\hline \multicolumn{2}{|c|}{ E-mail } \\
\hline Advantages & $\begin{array}{l}\text { Very fast and can handle large volumes of paper. Public e-mail facilities } \\
\text { are also available in public institutions (e.g. universities, libraries), and } \\
\text { the feedback from everyone can be instant and guaranteed. }\end{array}$ \\
\hline Disadvantages & $\begin{array}{l}\text { The average undereducated and elderly people do not have e-mail and } \\
\text { computer skills to access electronic mail. Also people particularly in } \\
\text { rural areas might have no access to computers. }\end{array}$ \\
\hline $\begin{array}{l}\text { Costs vs. } \\
\text { Benefits }\end{array}$ & $\begin{array}{l}\text { The cost of data transferring and processing are low, the preparation of } \\
\text { the evaluation, the summary and the feedback are fast and easy. Also } \\
\text { publishing is more efficient and timely via email and has a minimal cost. }\end{array}$ \\
\hline $\begin{array}{l}\text { Impact on } \\
\text { Legislation }\end{array}$ & $\begin{array}{l}\text { Internet and e-mail provide an important tool for the sharing of } \\
\text { information and also makes closer the communication gap between the } \\
\text { populace and the persons competent to draft the legislation. }\end{array}$ \\
\hline
\end{tabular}

Source: Based on Mijiga (2001)

The draft, which is submitted for concurrent consultation with government agencies, needs to be published - in line with the objective and entry into force of the draft - in a way to allow sufficient time for the substantive appraisal of the draft, as well as for expounding opinions and considering the merits of the received comments. ${ }^{23}$ The deadline for making comments is the same as that set in the course of submitting the draft for consultation with government agencies; in an exceptional case, the minister competent to draft the legislation may determine a different deadline. These deadlines are often very tight, the average number varies between a couple of days and 10 days, which depends on the length, contents and the importance (new act or just a simple, technical amendment) of the legislation. This practice is not against the law as there is no legal minimum defined for the period of submitting opinions, but it definitely limits the possibility to draw up and submit opinions.

21 In accordance with the provisions of Act CXII of 2011 on Informational Self-Determination and Freedom of Information and Act CXXXI of 2010 on Public participation in the drafting of legislation, Article, 9

22 Act CXXXI of 2010 on Public participation in the drafting of legislation, Article, 9

23 Act CXXXI of 2010 on Public participation in the drafting of legislation, Article, 10 
Table 2. Main statistics of public consultations' deadlines (the number of days between date of package and deadline for submitting views) 2011-2014

\begin{tabular}{|c|c|c|c|c|c|}
\hline & $\begin{array}{c}\text { Number of } \\
\text { preparatory } \\
\text { packages }\end{array}$ & Mean & $\begin{array}{c}\text { Median } \\
\text { (days) }\end{array}$ & Min-Max & $\begin{array}{c}\text { Average days between } \\
\text { introduction and } \\
\text { publication of a bill }\end{array}$ \\
\hline 2011 & 65 & 7.66 & 6.00 & $0-35$ & 41.8 \\
\hline 2012 & 66 & 6.94 & 5.50 & $1-43$ & 46.3 \\
\hline 2013 & 74 & 7.19 & 6.00 & $0-31$ & 40.8 \\
\hline 2014 & 13 & 4.38 & 5.00 & $0-12$ & 51.1 \\
\hline Total & 218 & 7.09 & 6.00 & $0-43$ & 45.0 \\
\hline
\end{tabular}

Source: Corruption Research Centre (CRC, 2015)

After the deadline, the minister responsible for drafting the legislation considers the received comments and prepares a general but typified summary on them, and, in the case of rejected comments, on the reasons for rejection, which shall be published together with the list of commenters on the website. ${ }^{24}$ The minister competent to draft the legislation stands under no obligation to respond individually. The summary to be prepared in the case of a law needs to be published after submission to the National Assembly, and in the case of a government or ministerial decree, after the promulgation. At the request of the parliamentary committee discussing the proposed legislation, comments received on the published legislative draft are made available to the committee. Probably partly because of the tight deadlines and the passive way the ministries solicit feedback, the number of these summaries is very low. Between 2011-2014, only 22 document packages included a summary of the public consultation a total of $8.5 \%$ of all packages (CRC, 2015, p. 26).

On the website, contacts are available for at least sixty days to allow any person to make comments, raise problems and make recommendations to the drafters of the legislation

- concurrently with the subsequent impact study, subject to the decision of the minister competent;

- following entry into force in the case of a law, as necessary but after at least one year has passed, in the case of a government decree and ministerial decree, subject to the decision of the minister competent. ${ }^{25}$

All persons who have made comments in the course of the preliminary consultation of the draft legislation are notified by electronic means of the possibility of making comments - except for subsequent comments made concurrently with the subsequent impact study - related to its entry into force.

24 Act CXXXI of 2010 on Public participation in the drafting of legislation, Article, 11 25 Act CXXXI of 2010 on Public participation in the drafting of legislation, Article, 12 


\subsection{Direct Consultation}

Organized interest groups can play a vital role in communicating between the public and legislation (Kurtz, 1997, p. 15). The direct consultation is based on strategic partnerships between the relevant ministries and stakeholders, outstanding organisations. The minister responsible for drafting the legislation may decide to form a strategic partnership and hold working groups or agree on other forms of consultation with the partners. ${ }^{26}$ The minister competent to draft the legislation creates strategic partnership agreements with representatives of the stakeholders. By means of such agreements the minister establishes close cooperation with those organisations which are prepared to engage in mutual collaboration and which represent a wide range of social interests in drafting legislation, or carry out scientific activities, in the particular areas of law (hereinafter referred to as strategic partner).

The strategic partners can be non-governmental organisations, recognised churches, professional and scientific organisations, national minority selfgovernments, interest representation organisations, public bodies, and higher educational institutions. The minister responsible for drafting the legislation may also involve others than the strategic partners, in a direct consultation held on a given draft law. The minister creates strategic partnership agreements with those churches in respect of which the Government has previously determined the framework of cooperation by way of legislation or an act regulating public law organisations. The previous Act LXV of 1990 on Local Self-Governments was rendered null and void by the new Act on Local Governments in Hungary. Its definition was useful and helpful for the Government and the minister to identify a stakeholder partner in the field of local governments. According to the provisions of the previous legislation, ${ }^{27}$ an organisation shall be considered as a national self-government interest representation organisation in a case where

- the association representing the interests of county self-governments includes at least 13 county self-governments in its membership,

- the association representing the interests of cities vested with county rank includes at least 15 local self-governments of cities vested with county rank in its membership,

- the association representing the interests of the Metropolitan SelfGovernment and metropolitan district self-governments includes the Budapest Metropolitan Self-Government and at least 15 metropolitan district self-governments in its membership,

- the association representing the interests of local self-governments functioning as district centres includes at least two thirds of such local self-governments in its membership, and

26 Compare with European Commission (2015)

27 Act LXV of 1990 on Local Self-Governments Section 103/C (It has been repealed) 
- any other organisation (association) representing the interests of local self-governments includes at least 800 local self-governments in its membership and has at least 11 regional (county) organisations in operation.

In calculating the ratios, one local self-government may be counted as a member of one interest representation association only.

The terms, conditions and framework of cooperation are laid down in an agreement between the strategic partner and the minister which shall remain in force for a fixed term but no longer than the end of the Government's term of office. ${ }^{28}$ The agreements can be accessible to all on the website. The agreement includes in particular the purpose of cooperation, the subject areas covered by the legislation for the drafting of which cooperation is established, the form of contact, the rules of access to information necessary for making comments, and the duration of the agreement.

The strategic partner has an obligation also to represent in the course of direct consultation the opinions of those organisations which are not engaged in the strategic partnership but specialise in the particular area of law. ${ }^{29}$ The minister competent to draft the legislation may also engage others, besides the strategic partners, in direct consultation on the legislative draft concerned and, upon request, allow participation in commenting on the particular legislation. At the request of the parliamentary committee discussing the proposed legislation, written comments made by the strategic partners in the course of direct consultation need to be made available to the committee.

In the event of consultation with personal attendance the parties are needed to be notified in writing about the time of the meeting in due time for preparation. ${ }^{30} \mathrm{~A}$ summary is made of the consultation with personal attendance, which shall be made public on the website. The summary contains the positions represented by the strategic partners and their rationale.

It is important to highlight that if the law provides expressly the right of a state or local government or other organizations to express an opinion and evaluation on the drafts, the preparer of the legislation must ensure that the body must be allowed to exercise this right. It shall be the responsibility of the minister competent to draft the legislation to open and conduct public consultation and to process the comments received.

\section{Summary and Conclusion}

The regulatory background demonstrates that a wide range of public participation possibilities is offered both for individuals and to civil society

28 Act CXXXI of 2010 on Public participation in the drafting of legislation, Article, 13

29 Act CXXXI of 2010 on Public participation in the drafting of legislation, Article, 14

30 Act CXXXI of 2010 on Public participation in the drafting of legislation, Article, 15 
organisations in the public-decision making and law-making processes in Hungary. The framework of the legal guarantees is laid down in the Fundamental Law in accordance with the EU law, and defined precisely in the relevant law sources: Act CXXX of 2010 on Legislation and Act CXXXI of 2010 on public participation in the drafting of legislation. According to these principles in the course of public consultation and drafting legislation the widest possible range of comments need to be ensured, and those need to be made public; the transparency and maximum publicity of consultations need to be provided; the participants are obliged to act in cooperation. It is the responsibility of the minister competent to draft the legislation to open and conduct the public consultation and to process the comments received. The forms of public consultation are the following: making comments via the link available on the website (general consultation), and comments made by persons, institutions and organisations engaged by the minister competent to draft the legislation (direct consultation). The general consultation is mandatory and open for the public, all draft bills, governmental decrees and ministerial decrees drafted by ministries are to be published on the Government's webpage (GRECO, 2015). Everyone is entitled to make comments on the draft or concept submitted for public consultation via the electronic mail address provided on the website. This right of petition can be exercised by anybody, who is entitled by rights from the Fundamental Law and is entitled to participate in public affairs, which means every natural person without prejudice to their nationality and residence. The direct consultation is based on strategic partnerships between the relevant ministries and stakeholder, outstanding organisations. This form provides and guarantees that the relevant stakeholders can express their opinions and demands in a formal way.

According to the above mentioned, it is clear that after 2010 the drafting of legislation has become disclosed and public. The availability of the drafts is easy either for the interested members of the populace or for the relevant stakeholders, law enforcementagencies, civil organizations and representative bodies. Thanks to the public participation and consultations, the governmental public policy making is getting closer and closer to the public demands. For a significant good example, tripartite negotiations can be found between the government, the stakeholders of the employers (Confederation of Hungarian Employers and Industrialists, National Association of Entrepreneurs and Employers, Hungarian Industrial Association etc.) and the representative bodies of employees (trade unions, public bodies) on the following matters: amount of minimum wages, burdens and social contributions on salaries, or the ratio of the income tax. But as a guarantee, according to the applicable legal provisions, opinions can be expressed on the final drafts by any other person, who has different concept. Finally, it can be concluded, that the legal background set up a well-functioning framework for the participation in the drafting of legislation, which guarantees and strengthens - by mandatory and optional processes - the legitimacy and the acceptance of legislation. 
László Vértesy

László Vértesy, PhD jur. PhD œc. is an associate professor at the National University of Public Service, Faculty of Public Administration in Hungary. Since 2005, he has been teaching in the higher education, participating in conferences in Hungary and in other countries (Italy, France, Belgium, Portugal, Slovakia, Serbia, Romania etc.) too. His work encompasses a number of fields: law and economics, in jurisprudence: administrative law (state and municipal administration, administrative procedure, efficiency and management, public tasks, good governance, e-administration), financial law, banking and commercial law; and in economics: macroeconomics, financial sector (banking, insurance, stock exchange), monetary and fiscal policy, business cycle. 


\section{References}

Baker, J. R., Bennett, L. L. M., Bennett, S. E., Flickinger, R. S. (1996). Citizens' Knowledge and Perceptions of Legislatures in Canada, Britain and the United States. The Journal of Legislative Studies, 2(2), 44-62. doi:10.1080/13572339608420471

CRC - Corruption Research Centre. (2015). Impact Assessments Public Consultation and Legislation in Hungary 2011-2014. Budapest: Corruption Research Centre. Available at http://www.crcb.eu/wp-content/ uploads/2015/07/legislation_2014_report_150630.pdf

Csink, L., Schanda, B., Varga, A. Zs. (2012). The Basic Law of Hungary - A First Commentary. National Institute of Public Administration. Available at https:// www.eui.eu/Documents/General/DebatingtheHungarianConstitution/ TheBasicLawofHungary.pdf

EC - European Commission. (2015). Better Regulation: Guidelines on Stakeholder Consultation. Available at http://ec.europa.eu/smart-regulation/guidelines/ ug_chap7_en.htm

Fridli, J., \& Paskó, I. (2000). Társadalmi szervezetek a jogalkotásban. Társaság a Szabadságjogokért. Budapest. Available at: http://tasz.hu/files/tasz/imce/ tarsadalmisz_ajogalkban.pdf

GRECO - Group of States against Corruption. (2015). Corruption prevention in respect of members of parliament, judges and prosecutors. Evaluation Report Hungary [Greco Eval IV Rep (2014) 10 E]. Strasbourg: Council of Europe, Group of States against Corruption. Available at https://rm.coe.int/ CoERMPublicCommonSearchServices/DisplayDCTMContent?documentld=09 000016806c6b9e

Kurtz, K. T. (1997). Legislatures and Citizens: Public Participation and Confidence in the Legislature. Trust for Representative Democracy. National Conference of State Legislatures. Available at http://www.ncsl.org/legislators-staff/ legislators/trust-for-representative-democracy/public-participation-andconfidence-in-the-leg541.aspx

Marzocci, O. (2016, October). The right of petition. Available at http://www. europarl.europa.eu/atyourservice/en/displayFtu.html?ftuld=FTU_2.1.4.html

Mijiga, F. (2001). Public Participation in the Legislation Process. National Democratic Institute.

NTH - Nemzetgazdasági Tervezési Hivatal. (2012). Mit érdemes tudni a társadalmi egyeztetésekröl - Módszertani segédlet a társadalmi-szakmai egyeztetések (konzultációk) lebonyolításához. Available at https://www.nth.gov.hu/hu/ media/download/206

OECD. (2015). Hungary: Towards a Strategic State Approach. OECD Public Governance Reviews. Paris: OECD Publishing. doi:10.1787/9789264213555en

Peters, Jr., R. M. (1978). The Massachusetts Constitution of 1780: A Social Compact. Amherst: University of Massachusetts Press.

Pring, G., \& Noé, S. Y. (2002). The Emerging International Law of Public Participation Affecting Global Mining, Energy, and Resources Development. In D. N. Zillman, A. Lucas, G. Pring (Eds.), Human Rights in Natural Resource Development. Oxford University Press.

doi:10.1093/acprof:oso/9780199253784.003.0002 
László Vértesy

\section{Legal sources}

Charter of Fundamental Rights of the European Union

Council Directive 90/313/EEC of 7 June 1990 on the freedom of access to information on the environment

Directive 2003/4/EC of the European Parliament and of the Council of 28 January 2003 on public access to environmental information and repealing Council Directive 90/313/EEC

Fundamental Law of Hungary

Act CLXXXIX of 2011 on Local Governments

Act CXXX of 2010 on Legislation

Act CXXXI of 2010 on Public participation in the drafting of legislation

Act LXV of 1990 on Local Self-Governments Section

Decree No. 12/2016. (IV. 29.) of the Minister of the Prime Minister's Office on Ex-ante and Ex-post Impact Assessment

Decree No. 24/2011 (VIII.9.) of the Minister of Public Administration and Justice On Ex-ante and Ex-post Impact Assessment 


\subsection{Strokovni članek}

\section{Javno sodelovanje pri pripravi zakonodaje na Madžarskem}

Javno sodelovanje pri pripravi zakonodaje je eden ključnih elementov pri legitimnosti in sprejemanju zakonodaje. $V$ povezavi s temo se pojavlja vprašanje, kako lahko država to okrepi ter kako lahko državljane učinkoviteje vključi v postopek priprave zakonodaje. Glavno hipotezo je mogoče oblikovati kot vprašanje, ali lahko pravna obveznost javnega sodelovanja in obvezna javna posvetovanja izboljšajo legitimnost zakonodaje. Naslednje vprašanje je, ali obstoječa zakonodaja zagotavlja primeren okvir za vključitev organizacij civilne družbe (OCD) in ljudstva, z uporabo svetovalne moči, v zakonodajni postopek. Glavni cilj tega prispevka je predstaviti in analizirati proces sodelovanja javnosti, pritegniti pozornost na najpomembnejše madžarske tehnike in oceniti rezultate. Eden izmed ciljev je pokazati, ali pravila v praksi delujejo in ali so skladna z želenimi političnimi in družbenimi prizadevanji. Naslednji namen je pritegniti pozornost politikov na to tehniko, ki jo je mogoče uporabiti kot najboljšo prakso za druge države. Raziskava temelji predvsem na zakonodajni metodologiji s kvantitativnim pristopom.

Vse sodobne ustave in temeljni zakoni vsebujejo in razglašajo koncept in princip suverenosti, kar dejansko pomeni, da so ljudje končni vir javne moči in vlade. Zato imajo ljudje implicitno pravico, da neposredno sodelujejo v procesu priprave zakona. V skladu z 41. členom Listine o temeljnih pravicah Evropske unije lahko vsaka oseba piše institucijam Unije v enem izmed jezikov Pogodb ter mora prejeti odgovor v istem jeziku. 44. člen opredeljuje pravico do peticije. Vsak državljan Unije in vsaka fizična ali pravna oseba s prebivališčem ali sedežem podjetja v državi članici ima pravico do peticije $v$ Evropskem parlamentu. Vendar sodelovanje javnosti pri pripravi zakonodaje ni vključeno. Za izvajanje teh določb VI. člen Temeljne zakonodaje Madžarske navaja, da ima vsak pravico do zaščite osebnih podatkov ter dostopa in posredovanja podatkov, ki so v javnem interesu. V skladu z zakonodajo EU XXV. člen Temeljne zakonodaje Madžarske navaja, da ima vsak pravico predložiti, sam ali skupaj z drugimi, pisne vloge, pritožbe ali predloge kateremu koli organu, ki izvršuje javna pooblastila. Pravico do peticije lahko uporabi vsakdo, ki ima pravico iz Temeljne zakonodaje in lahko sodeluje v javnih zadevah.

Ob koncu 80. let je na Madžarskem mogoče najti nekatere določbe javnega sodelovanja (Zakon XI iz 1987 o zakonodaji), vendar v praksi niso bile uporabljene ter so izhajale iz politične preobrazbe. Trenutno zakon CXXX iz leta 2010 o zakonodaji natančno opredeljuje najpomembnejše zahteve priprave zakona, vendar se bo $v$ našem primeru prispevek osredotočil na pripravo. Državni zbor je 22. novembra 2010 sprejel zakon CXXXI iz 
leta 2010 o javnem sodelovanju pri pripravi zakonodaje za spodbujanje vključenosti najširšega mogočega obsega družbenih segmentov pri razvoju zakonodaje znotraj okvira dobrega upravljanja, s čimer je postavil temelje široki zakonodaji, ki bo služila javnemu dobremu ter tako izboljšala kakovost in izvršljivost zakonodaje, ki skupaj tvorita nepogrešljive pogoje dobre države. Primarni instrument javnega sodelovanja pri pripravi zakonodaje je javno posvetovanje. Terminologija javnega posvetovanja, ki je opredeljena z Zakonom kot kakršni koli komentarji fizičnih oseb ter nevladnih in neobčinskih organizacij o zakonodajnih predlogih, ki jih pripravijo ministrstva. Obseg tem je zares širok. Komentatorji so lahko posamezne fizične osebe ter (z ohranjanjem neodvisnosti) nevladne in neobčinske organizacije: združenja, fundacije, zbornice, javni organi, interesni predstavniški organi, sindikati, zagovorniki človekovih pravic, druge interesne skupine ter tudi poslovne in gospodarske družbe. Oblike javnega posvetovanja so naslednje: komentiranje preko povezave na spletni strani (v nadaljnjem besedilu splošno posvetovanje) in komentarji oseb, institucij in organizacij, ki jih aktivira minister, pristojen za pripravo zakonodaje (v nadaljnjem besedilu neposredno posvetovanje).

Splošno posvetovanje je v okviru javnega posvetovanja obvezno v vseh primerih. Osnutek ali koncept, ki je predložen v javno razpravo, mora biti javen in dostopen na spletni strani. Poleg osnutka je treba predložiti povzetek predhodne ocene učinka. Na vsaki domači strani madžarskih ministrstev (http://www.kormany.hu) je mogoče najti povezavo z naslovom "splošno posvetovanje«. Na tej povezavi je dolg seznam ustreznih osnutkov, kjer se nahajajo tema, popolno besedilo s pojasnilom v obliki PDF, datum objave, rok za oddajo komentarjev in uradni naslov elektronske pošte za prejem. Vsakdo ima pravico komentirati osnutek oziroma koncept, predložen v javno razpravo, preko elektronskega naslova na spletni strani. Z uporabo elektronskega naslova, objavljenega na spletni strani, lahko ljudje izrazijo mnenje o osnutku ali konceptu v javni razpravi. Da bi zagotovili dovolj velik pomen splošnega posvetovanja, anonimni komentarji niso upoštevani in so izbrisani. Osnutek, ki je predložen za sočasno razpravo z vladnimi agencijami, mora biti objavljen na način, ki dovoljuje dovolj časa za vsebinsko presojo osnutka ter pojasnjevanje mnenj ter presojo utemeljenosti prejetih komentarjev. Po preteku roka minister, odgovoren za pripravo zakonodaje, pregleda prejete komentarje in pripravi njihov splošni povzetek ter v primeru zavrnjenih komentarjev tudi razloge za zavrnitev, kar se skupaj s seznamom komentatorjev objavi na spletni strani. Povzetek je treba pripraviti v primeru, da je treba zakon objaviti po predložitvi v Državni zbor, ter v primeru vladnega ali ministrskega odloka po razglasitvi.

Neposredno posvetovanje temelji na strateškem partnerstvu med pristojnimi ministrstvi in interesnimi skupinami, izjemnimi organizacijami. Strateški partnerji so lahko nevladne organizacije, priznane cerkve, strokovne in znanstvene organizacije, nacionalne manjšinske samouprave, organizacije interesnih predstavnikov, javni organi in visokošolske institucije. Minister, 
odgovoren za pripravo zakonodaje, lahko $v$ neposredno posvetovanje o osnutku zakona vključi tudi druge partnerje, ki niso strateški partnerji. Minister ustvarja strateške partnerske sporazume s tistimi cerkvami, za katere je vlada že prej določila okvir sodelovanja na podlagi zakonodaje oziroma zakona o organizacijah javnega prava. Pravila in pogoji ter okvir sodelovanja so določeni v sporazumu med strateškim partnerjem in ministrom, ki morajo ostati v veljavi določeno obdobje, vendar ne dlje kot do konca mandata vlade. Sporazumi so vsem na voljo na spletni strani. Sporazum vključuje zlasti namen sodelovanja, vsebinska področja, ki jih pokriva zakonodaja za pripravo osnutka, za katero je vzpostavljeno sodelovanje, obliko stika, pravila dostopa do informacij, ki so potrebne za komentiranje, in trajanje sporazuma. Strateški partner mora v procesu neposrednega posvetovanja zastopati tudi mnenja organizacij, ki niso vključene v strateško partnerstvo, vendar so specializirane za določeno področje prava. Povzetek je narejen iz posvetovanja z osebno udeležbo in mora biti javno dostopen na spletni strani. Povzetek vsebuje stališča, ki jih zastopajo strateški partnerji, in njihove razloge. Pomembno je poudariti, da če zakon izrecno zagotavlja pravico države ali lokalne samouprave oziroma drugih organizacij do izražanja mnenja in ocene osnutkov, mora pripravljavec zakonodaje zagotoviti, da lahko organ to pravico izvaja.

V skladu z zgoraj omenjenim je jasno, da je po letu 2010 priprava zakonodaje postala razkrita in javna. Dostop do osnutkov je enostavnejši za zainteresirane člane ljudstva ali ustrezne zainteresirane strani, organe kazenskega pregona, civilne organizacije in predstavniške organe. Zaradi javnega sodelovanja in posvetovanja so vladne priprave zakonodaje vedno bliže javnim zahtevam. Izjemno dober primer so tristranska pogajanja med vlado, zainteresiranimi skupinami delodajalcev (Združenje madžarskih delodajalcev in industrialcev, Nacionalno združenje podjetnikov in delodajalcev, Madžarsko industrijsko združenje itd.) in predstavniškimi organi zaposlenih (sindikati, javni organi) o naslednjih zadevah: višina minimalnih plač, obremenitve in socialni prispevki iz naslova plač, razmerje davka od dohodka. Toda kotjamstvo v skladu z veljavnimi predpisi lahko mnenje o končnih osnutkih izrazi tudi oseba z drugačnim konceptom. Na koncu je mogoče ugotoviti, da pravno ozadje vzpostavlja dobro delujoč okvir za sodelovanje v pripravi zakonodaje, ki zagotavlja in krepi (z obveznimi in izbirnimi postopki) legitimnost pri sprejemanju zakonodaje. 